\title{
Ability to write a Reader's Letter About the School Environment in 03 Lumbir State Junior High School
}

\author{
Nur Amalia Solikhah ${ }^{1 凶}$, Destia Herlisya ${ }^{2}$ \\ ${ }^{1}$ Bina Sarana Informatika University, Central Java, Indonesia \\ ${ }^{2}$ STKIP PGRI Bandar Lampung, Lampung, Indonesia \\ $\otimes_{\text {email: nur.nlk@bsi.ac.id }}{ }^{1}$
}

Received:

July 2021

Revised:

August 2021

Accepted:

August 2021

Published:

August 2021

\begin{abstract}
The issues examined in this research relate to the students' ability in writing letters of readers about the school environment. This research uses descriptive quantitative methods, and sampling techniques used are random class (random cluster). Engineering data collection using the technique of main performance writing letters to readers about the school environment. The technique of data analysis using quantitative analysis with the descriptive approach. Based on research results, students' ability to write letters of readers about the school environment belongs simply because final value shows number 67 . The constraints experienced by students in writing letters of readers about the school environment i.e., students still lack understanding about the reader's letters, and the difficulty of applying aspects of mail readers. The most prominent obstacle experienced by students in writing letters to readers about the theme of the school environment is the difficulty of applying Indonesian spelling properly and correctly.
\end{abstract}

Keywords: Writing, Communication, Students' Characteristic, letters of reader, 03 Lumbir

\section{INTRODUCTION}

Humans are created as social creatures who need the means to interact with other humans in society. The existence of this social interaction requires a means of communication called language. A language is a tool used by humans to interact or communicate, in the sense that a tool is to convey thoughts, ideas, concepts, or feelings to others. Many things can be done to convey messages to other people, one of which is by writing. 
Writing skill is one of the communication activities in delivering messages (information) in writing to other parties using written language as a tool or medium (Dalman: 2014). In line with this opinion, Rosidi (2009) argues that writing is an activity to express one's thoughts, ideas, and feelings expressed in written language.

The medium for delivering messages in written form, which is still in use today, is letters. A letter is a piece of paper, even more so that it creates communication in writing. Even though the times have become more modern, not a few students still like writing correspondence. Through letters, we can convey ideas or feelings to other people who are far apart very easily and are more memorable than electronic media. Marjo (2011) stated that letters are a means of written communication or conveying written statements or information from one party to another. This information can be in the form of notifications, statements, questions, requests, reports, thoughts, rebuttals, etc. In line with this, Ali (2009) argues that a letter is a piece of paper or more to establish written communication or relationships.

The writing skills of students are directed to write letters from readers, according to the applicable competency standards (henceforth $S K$ ) and basic competencies (henceforth $K D$ ) of the education unit level curriculum (henceforth $K T S P)$. The competency standard (SK) is to express thoughts, feelings, and information in the form of simple scientific works, speech texts, readers 'letters, and basic competence (henceforth $K D$ ) is to write readers' letters about the school environment (Wahono, 2009). Writing a reader letter on the school environments topic is necessary for students for several reasons. First, the material follows competency standards (henceforth $S K$ ) and basic competence (henceforth $K D$ ), so that students can convey various aspirations, complaints, criticisms, or suggestions related to the problems appear in the school environment and can convey it well and politely. In addition, the school environment is the right place for the student learning process in conveying aspirations to those in the school environment.

Reader's letter is an open letter containing complaints, suggestions, praise, and criticism, can be read by anyone, and addressed to institutions, governments, companies, offices, groups, or organizations. Jauhari (2013) that a reader's letter is personally addressed to a person, group, agency, company, and others. Readers' letters contain the reader's ideas, feelings, or thoughts about an issue usually related to public issues published in a special column/rubric in print media (Iriantara and Surachman, 2011).

Based on the pre-research activities that were carried out at SMP Negeri 03 Lumbir odd semester on November 18, 2020, it was found that the students' ability to write letters from readers was still unsatisfactory. Students do not have enough knowledge about writing reader's letters, both the procedures for writing reader's letters and the use of language. In addition, there were still spelling rules irregularities, both in capital letters and punctuation. In addition, to these deviations, the message or information conveyed is also considered not to represent 
the thoughts of the reader letter writer. Information on these problems was obtained from the Indonesian language teacher.

\section{METHOD}

This research includes quantitative research using descriptive methods. The subjects of this study were students of class IX 03 Lumbir state junior high school with 32 students. The research site was conducted at 03 Lumbir state junior high school. The research instrument was a performance test of the ability to write letters from readers about the school environment in class IX students of 03 Lumbir state junior high school.

The data collection technique in this study was carried out by providing the performance of writing a reader's letter about the school environment by paying attention to the aspects of the correct reader letter information, the characteristics of the complete reader's letter, and the correct sentence and spelling.

The data analysis technique used is to analyze the data obtained from the research subjects, namely students of class IX 03 Lumbir state junior high school with the following steps, a) correcting the research data, namely letters from readers written by students about the school environment; and b) provide scoring off the readers' letters written by students based on the predetermined aspects of the assessment. The scoring guidelines are as follows.

Table 1. Guidelines for Student Readers' Letters

\begin{tabular}{|c|c|c|c|}
\hline No & Indicator & Description of Achievement & score range \\
\hline 1 & Delivery of information & $\begin{array}{l}\text { a. Delivery of information is } \\
\text { appropriate/appropriate } \\
\text { b. Information delivery is a quite } \\
\text { relevant } \\
\text { c. Information delivery is less } \\
\text { relevant } \\
\text { d. Inaccurate information delivery }\end{array}$ & $\begin{array}{l}4 \\
3 \\
2 \\
1\end{array}$ \\
\hline 2 & $\begin{array}{l}\text { Writing characteristics of } \\
\text { the reader's letter }\end{array}$ & $\begin{array}{l}\text { a. The characteristics of the } \\
\text { reader's letter are complete and } \\
\text { correct } \\
\text { b. There are 1-2 characteristics of a } \\
\text { reader's letter wrong } \\
\text { c. There are 3-4 characteristics of a } \\
\text { reader's letter wrong } \\
\text { d. None of the characteristics of } \\
\text { the reader's letter are correct }\end{array}$ & $\begin{array}{l}3 \\
2 \\
1\end{array}$ \\
\hline 3 & Sentence accuracy & $\begin{array}{l}\text { a. Exact sentences } \\
\text { b. There are 1-5 sentence errors } \\
\text { c. There are 6-10 sentence errors }\end{array}$ & $\begin{array}{l}4 \\
3 \\
2\end{array}$ \\
\hline
\end{tabular}




\begin{tabular}{|l|l|l|c|}
\hline & & d. There are $\geq 11$ sentence errors & 1 \\
\hline 4 & Spelling accuracy & a. Spelling is correct & 4 \\
& & b. There are $1-5$ misspellings & 3 \\
& & c. There are $6-10$ misspellings & 2 \\
& d. There are $\geq 11$ spelling errors & 1 \\
\hline \multicolumn{2}{|l|}{ Score } & 16 \\
\hline
\end{tabular}

(Adapted from Nurgiyantoro, 2013: 437)

Processing or calculating the scores of students in writing letters to readers about the school environment with the formula to obtain the average (mean) value of students. According to Nurgiyantoro (2013), a formula is used to find the average:

$$
\text { Score: } \frac{\text { Total Score }}{\text { Maximum Score }} \times 100
$$

The results of the value calculation are adjusted to the ability level criteria.

Table 2. Measures for Classification of Students' Abilities

\begin{tabular}{|c|c|c|}
\hline Mastery Level & Standard Score / Value & Information \\
\hline $90 \%-100 \%$ & $\mathrm{~A}$ & Very Good \\
\hline $80 \%-89 \%$ & $\mathrm{~B}$ & Good \\
\hline $65 \%-79 \%$ & $\mathrm{C}$ & Enough \\
\hline $55 \%-64 \%$ & $\mathrm{D}$ & Less \\
\hline $0 \%-54 \%$ & $\mathrm{E}$ & Very Less \\
\hline
\end{tabular}

(Wahyuni dan Ibrahim,2012)

Explain the inaccuracy of students writing readers' letters about the school environment, and conclude at the study's end.

\section{FINDINGS AND DISCUSSION}

The research stage was conducted in one meeting by conducting a performance test of the ability to write letters from readers about the school environment of class IX students of 03 Lumbir junior high school. The total score obtained in writing a reader's letter about the school environment is viewed from 4 aspects, namely the delivery of information, writing characteristics of the reader's letter, sentence accuracy, and spelling accuracy all reached 2143 with an average score of 67 .

The highest percentage of students' ability is in the sufficient criteria, namely the range 65-79 with the total relative frequency of 13 students and the cumulative frequency of $41 \%$. Meanwhile, 1 student or $3 \%$ is in very good ability with a score of 94,3 students (9\%) are in good ability, 12 students (38\%) are in 
low ability, and 3 students (9\%) are in the very poor category. Thus, it can be stated that the ability of students to write letters from readers about the school environment is in the sufficient category or is close to the minimum completeness criteria (henceforth $K K M$ ). It will be declared successful in Indonesian subjects if the score obtained is not less than 70 .

The ability to write letters from readers about the school environment based on delivering information is known that the total student score reaches 2525 with an average value of 79 . The ability of students with the highest percentage is in very good criteria, namely the range 90-100 with the number of relative frequencies 17 students and the cumulative frequency of $53 \%$. This success is due to students understanding of the reader's letter material relating to the information to be conveyed in the reader's letter. So that students can write letters from readers about the school environment according to predetermined topics without extending to other topics. However, there were 9 students (28\%) who were in the very poor category. This is because 9 students do not understand the topics and information in the reader's letter. This can be seen from the existence of 6 students who wrote letters from readers instead of containing appeals or invitations, and 3 students writing information about the reader's letters that were not according to the predetermined topic. Even though 9 students were in the very poor category, 6 students (19\%) were in the sufficient category, and no sample was included in the good and poor categories. Thus, it can be concluded that the ability of students to write letters from readers about the school environment based on the aspect of delivering information is in the sufficient category.

Based on the writing aspect of the characteristics of the reader's letter, the overall score is the same as the previous aspect, namely reaching 2525 with an average score of 79 . The ability of the highest percentage of students is in the sufficient criteria, namely the range 65-79 with the number of relative frequencies 23 students and the cumulative frequency of $72 \%$. Apart from 23 students who were in the sufficient category, there were 7 students $(22 \%)$ who were in the very good category. 2 students $(6 \%)$ were in the very poor category, and no sample was in the good and poor categories. The errors of 23 students in the quite average category were the same, namely in writing letters, the readers still used language that was difficult to understand. In addition, some did not include their complete identity when writing the reader's letter, while 2 students were in the very poor category due to a lack of understanding of the characteristics of the reader's letter.

The ability of students to write letters from readers about the school environment based on the aspect of sentence accuracy was obtained by a total student score of 2275 and the sample in this study amounted to 32 students. After the data is managed, an average of 71 is obtained. Thus, it can be concluded that the ability of students to write letters from readers about the school environment based on the aspect of sentence accuracy is in the sufficient category. Information was obtained that students with the highest percentage were in the sufficient 
criteria, namely the range 65-79 with the number of relative frequencies of 25 students and the cumulative frequency of $78 \%$.

Meanwhile, only 1 student (3\%) was in the very good category, 6 students (19\%) were in the very poor category, and no sample was included in the good and poor categories. There are 31 students have similar errors. This error is that in writing a reader's letter, sentence by sentence that is used is still not effective. Of the 31 students, 9 students had too many error rates, so they were very poor. Thus, it is necessary to hold a serious evaluation related to sentence writing so that students ability to write letters from readers is getting better.

In the last aspect, namely the aspect of spelling accuracy, it was obtained that the total student score reached 1200 with a sample of 32 students. After the data was managed, an average of 38 was obtained. Thus, it could be said that the students' ability to write letters from readers about the school environment based on spelling accuracy was in the very poor category. This can be seen from the students' ability, the highest percentage is in the very poor criteria, namely the range 0-54 with the relative frequency of 29 students and the cumulative frequency of $91 \%$. Most of the students' mistakes were the same, namely, the spelling used, such as capital letters and punctuation, was incorrect. Apart from the 29 students who were in the very poor criteria, 3 students (9\%) were in the sufficient category, and none were in the very good, good, and poor categories.

Judging from the available data, students are stated to have still not succeeded in writing a reader's letter about the school environment based on spelling accuracy because the final score of 38 has not reached the KKM even far below the KKM score, which is ideally 70. The follow-up is that 29 very lacking students must be evaluated more seriously because spelling accuracy in writing reader's letters about the school environment is important in the assessment. The evaluation also applies to 3 students with sufficient criteria.

\section{CONCLUSION}

Based on the data above, it can be concluded that the ability of grade IX even semester students of 03 Lumbir state junior high school in the 2020/2021 school year in writing a reader's letter about the school environment is quite sufficient because the final score shows a value of 67 .

Furthermore, the conclusions of the results of the analysis of each aspect are as follows; in the aspect of delivering information, out of 32 students 17 students got the maximum score, namely $4 ; 6$ students scored 3 or moderate, and 9 students got the lowest score. The final average score obtained by the students was 79 and it was in the sufficient category. 
In the writing aspect of the student's reader letter's final score was 79 . Of the 32 students, 7 students got the maximum score; 23 students scored 3 or moderate, and only 2 students scored the lowest. In the aspect of sentence accuracy, the student's average score reached 71 in the sufficient category, and only 1 student got the maximum score; 25 students got a score of 3 or moderate, and 5 students get the lowest score. Meanwhile, in spelling accuracy, the student's score shows the number 38 so that it is in the very poor category. Of the 32 students, only 3 students got a score of 3; 29 students got low scores, and none of the students got the highest scores.

The obstacles experienced by students in writing reader's letters about the school environment are considered to still lack understanding of the reader's letter. It's especially the criteria for a reader's letter, such as delivering information. There are still some students who write a reader's letter instead containing an appeal so that the reader's letter is written regarding the results of the school environment are not optimal. Likewise, in the aspect of writing, the characteristics of the reader's letter and the accuracy of the sentence. There are still some students who write incorrectly and incorrectly.

The most prominent obstacle in writing letters to readers about the school environment experienced by students is the difficulty in applying Indonesian spelling, especially capital letters and punctuation. The students' constraints are due to the lack of practice in applying Indonesian spelling, especially capital letters and punctuation when writing, coupled with ignorance of these rules.

\section{REFERENCES}

Ali, Adelan. (2009). Panduan Lengkap Korespondensi. Jakarta: Eska Media.

Dalman. (2014). Keterampilan Menulis. Jakarta: PT. Raja Gravindo Persada.

Iriantara, Yosal dan Surachaman, Yani. (2011). Public Relations Writing. Bandung: Simbiosa Rekatama Media.

Jauhari, Heri. (2013). Terampil Mengarang. Bandung: Nuansa Cendekia.

Marjo, Y.S. (2011). Surat-surat Lengkap. Jakarta: Setia Kawan Press.

Nurgiyantoro, Burhan. (2013). Penilaian Pembelajaran Bahasa Berbasis Kompetensi. Yogyakarta: BPFE.

Rosidi, Imron. (2009). Menulis Siapa Takut. Yogyakarta: Kanisius. 